\title{
Chronic Obstructive Pulmonary Disease Is Negatively Related with Nasal Polyp in Middle Aged and Elderly Chronic Rhinosinusitis Patients
}

\author{
Min Gu Lee, Si Whan Kim, Jeong Hwan Yang, Ju Han Lee, and Hyo Geun Choi \\ Department Otorhinolaryngology-Head and Neck Surgery, Hallym University College of Medicine, Anyang, Korea
}

\section{중년 및 노인에서의 만성 폐쇄성 폐질환과 비용종 발생 감소의 상관성}

이민구 · 김시환 · 양정환 · 이주한 · 최효근

한림대학교 의과대학 이비인후과학교실

Received July 27,2015

Revised October 13,2015

Accepted October 21, 2015

Address for correspondence

Hyo Geun Choi, MD

Department Otorhinolaryngology-

Head and Neck Surgery,

Hallym University

College of Medicine,

22 Gwanpyeong-ro 170beon-gil,

Dongan-gu, Anyang 14068, Korea

Tel +82-31-380-3849

Fax $+82-31-386-3860$

E-mail pupen@naver.com
Background and Objectives Chronic obstructive pulmonary disease (COPD) is known to induce chronic rhinosinusitis (CRS). Nasal polyp, which is frequently found in patients with CRS, seems to have close relationship with COPD, but little is known about its relationship with COPD. In this study, we investigated the relationship between COPD and nasal polyp in middle aged and elderly CRS patients.

Subjects and Method We analyzed the clinical data of 174 patients (age of over 50 years) with CRS. Patients were divided as COPD [forced expiratory volume (FEV1)/forced vital capacity (FVC) $<70 \%, n=30]$ and non-COPD group (FEV1/FVC $\geq 70 \%, n=144$ ) according to the pulmonary function test results. Binary logistic regression analysis was used to describe the relationships between clinically relevant factors related to nasal polyp.

Results On logistic regression analysis, no significant relationship was found between age [adjusted odds ratio (AOR): $1.058,95 \%$ confidence interval for the difference $(\mathrm{CI})=0.995-$ 1.126, $p=0.073$ ], sex AOR: 0.897, 95\% CI=0.366-2.415, $p=0.897$ ), smoking (AOR: $0.434,95 \%$ $\mathrm{CI}=0.154-1.219, p=0.113$ ) and obesity (underweight AOR: $3.833,95 \% \mathrm{CI}=0.781-18.808, p=$ 0.098, overweight AOR: 5.169, 95\% CI $=0.996-26.814, p=0.051$, obese AOR: $2.911,95 \% \mathrm{CI}=$ $0.335-25.329, p=0.333$ ) with polyp. However, there was a negative correlation between COPD history and nasal polyp with statistical significance (AOR: $0.288,95 \% \mathrm{CI}=0.102-0.809, p=0.018$ ). Conclusion Our findings suggest that patients with COPD are less likely to have nasal polyp than patients without COPD. Korean J Otorhinolaryngol-Head Neck Surg 2016;59(4):287-92

Key Words Aged $\cdot$ Chronic obstructive pulmonary disease $\cdot$ Middle aged ·

Nasal polyps $\cdot$ Sinusitis.

\section{서 론}

상기도 질환과 하기도 질환이 서로 연관되어 있으며, 서로 유의한 상호관계를 보인다는 사실은 잘 알려져 있다. 최근에 는 두 질환이 서로 별개의 질환이 아닌 '하나의 연관된 호흡 기 질환으로 인식되고 있다. ${ }^{1,2}$ 많은 연구에서, 대표적인 상기 도 질환인 천식과 만성 비부비동염이 밀접한 연관을 가지고
있는 것이 보고되었으며, ${ }^{3,4}$ 최근 연구에서는 만성 폐쇄성 폐 질환에서도 만성 비부비동염이 유의하게 더 동반되는 것이 보 고되었다. ${ }^{5,6)}$

만성 비부비동염이란 비강과 부비동의 점막을 침범하는 지속적인 염증 반응을 의미한다. 만성 비부비동염과 비용종 의 진단 및 관리에 대한 지침인 'European Position Paper on Rhinosinusitis and Nasal polyps(EPOS)'에 따르면, 만성 비 
부비동염이란 전방, 또는 후방 비루, 코 막힘, 후각 감소, 비강 불편감 중 적어도 두 개 이상의 증상이 내과적 치료에도 불구 하고 12 주 이상 지속되며, 또는 비내시경 검사상 비용종, 농성 분비물 등 특징적인 소견이 관찰되거나, 전산화단층촬영상 부비동 개구 복합체나 부비동에 점막 변화가 있는 것을 말하 며, 이 중 중비도에 내시경으로 확인되는 비용이 동반되는 경 우를 비용이 동반된 만성 비부비동염, 중비도에 내시경으로 확인되는 비용이 동반되지 않는 경우를 비용이 동반되지 않은 만성 비부비동염이라고 한다.

만성 폐쇄성 폐질환은 완전 회복이 어려운, 지속적인 호기 량 제한으로 특징지어지는 호흡기 질환이며, 보통 폐의 비정 상적 염증 반응 또는 체중 감소, 빈혈, 골다공증 등과 같은 전 신 질환과 동반된다. ${ }^{8)}$ 만성 폐쇄성 폐질환의 진단 및 관리에 대한 지침인 Global Initiative for Chronic Obstructive Lung Disease statement에서는, 폐기능 검사를 chronic obstructive pulmonary disease(COPD) 환자의 진단 및 분류에 가장 중 요한 방법이라고 하였고, 폐기능 검사에서 1 초간 노력성 호기 량(forced expiratory volume, FEV1)/노력성 폐활량(forced vital capacity, FVC) 값이 70\% 미만일 때 만성 폐쇄성 폐질 환으로 정의한다고 하였다. ${ }^{9}$ 만성 폐쇄성 폐질환의 병리학적 변화는 크게 기도의 염증, 기질의 파괴로 나뉘며, 이는 각각 만성 기관지염, 폐기종으로 알려져 있다. 이러한 변화는 흡연 에 의해 주로 발생한다고 알려져 있는데, 최근 연구에 의하 면 만성 폐쇄성 폐질환 환자에서 혈관형성 및 혈관 투과를 조절하는 강력한 매개체 중 하나로 폐의 정상 구조 유지 및 폐 의 항상성에도 관여한다고 알려져 있는 vascular endothelial factor(VEGF) 및, VEGF의 발현을 유발하는 전사인자로 저 산소증 및 염증반응에 의해 촉진되는 hypoxia inducible factor-1 alpha(HIF-1 $1 \alpha$ )가 유의하게 증가하였으며, 이는 만성 폐쇄성 폐질환 환자에서 폐 손상의 기전으로 생각된다고 보 고하였다. ${ }^{10)} \mathrm{HIF}-1 \alpha$ 는 비용의 발생에도 중요한 원인으로 생 각되고 있다. 비용이 동반된 만성 비부비동염 환자의 점막에서 $\mathrm{HIF}-1 \alpha$ 가 증가되었고, 이는 비용의 발생에 기여한다고 알려져 있고, 만성 폐쇄성 폐질환 환자의 경우 기도 폐색에 의해 만성 저산소증이 발생하며, 이는 체내 HIF- $1 \alpha$ 의 발현을 촉진시키 므로 비용의 발생에도 영향을 미칠 것으로 생각된다. ${ }^{11}$ 특히 폐기능이 더 떨어지는 고령 환자의 경우 체내 저산소증이 더 심하므로 비용의 발생이 더 많을 것이라고 생각된다.

이에 본 연구에서는 50 세 이상의 중년 및 고령 만성 비부 비동염 환자를 대상으로 폐기능 검사 및 비내시경 검사를 시 행하여 만성 폐쇄성 폐질환과 비용종의 관계에 대해 조사하 였다.

\section{대상 및 방법}

본 연구는 2008년 3월부터 2014년 10월까지 병원 이비인 후과를 방문하여 비부비동 내시경 수술을 시행한 334명의 고령 만성 비부비동염 환자의 의무기록을 대상으로, 후향적 연구로 진행되었다. 초진 시, 문진과 비내시경 검사를 시행하 여 비용의 유무를 확인하였으며, EPOS의 진단기준에 따라, 농성비루 등 비부비동염의 증상이 3개월 이상 지속되며, 또 는 비내시경 검사상 비용종, 농성 분비물 등 특징적인 소견 이 관찰되거나, 전산화단층촬영상 부비동 개구 복합체나 부 비동에 점막 변화가 있는 경우에 만성 비부비동염으로 진단 하였으며, 이를 수술의 적응증으로 하였다. 이 중, 진균 감염 57 명, 술후상악동낭 31 명, 후비공폴립 11 명, 유두종 5 명, 자 가면역 질환 2 명, 암 1 명, 비강 이물 1 명은 연구대상에서 제외 하였다(총 108명).

천식과 만성 폐쇄성 폐질환은 대표적인 만성 호흡기 질환 이다. 두 질환 모두 호흡기관 내에 만성 염증을 일으키나, 그 기전 및 치료 방법은 매우 다르다. 본 연구에서는 연구 환자 군에서 천식 환자를 제외하기 위해, 환자 선택 시 천식의 과 거력이 있는 환자 27 명은 연구대상에서 제외하였다. 한편, 고 령 환자의 경우 천식과 만성 폐쇄성 폐질환의 증상이 겹쳐서 나타나는 경우가 많으며, 이를 천식-만성 폐쇄성 폐질환 동 반 증후군(asthma-chronic obstructive pulmonary disease overlap syndrome, ACOS)이라고 부르는데, 최근 연구에서는 $\mathrm{ACOS}$ 가 만성 폐쇄성 폐질환 환자군의 15 25\%를 차지한다 고 보고하였다. ${ }^{12)} \mathrm{ACOS}$ 환자의 확인을 위해 나머지 199 명 환 자 모두에게서 시행된 메타콜린 기관지 유발검사(methacholine bronchial provocation test)를 분석하였다. 메타콜린 기 관지 유발검사는 메타콜린 흡입 후 FEV1이 기저치의 20\%만 큼 감소할 때의 메타콜린의 농도(provocation concentration of methacholine causing a $20 \%$ fall, PC20)를 측정하여, $\mathrm{PC} 20$ 이 $25 \mathrm{mg} / \mathrm{mL}$ 이하인 경우를 $\mathrm{ACOS}$ 양성으로 정의하 였다. 나머지 199 명의 환자 중, 25 명의 환자가 메타콜린 기관 지 유발검사에서 양성으로 확인, $\mathrm{ACOS}$ 환자로 진단되어 연 구대상에서 제외하였다.

최종적으로, 총 174 명의 환자를 연구대상으로 확정하였다. 이 중 114 명이 남성, 60 명이 여성이었으며, 연령은 50 세에서 83세로 평균연령은 60 세였다. 모든 환자를 대상으로 폐기능 검사(pulmonary function test)를 시행하였다. 환자에게서 1초 간 노력성 호기량(FEV1)/노력성 폐활량(FVC)을 계산하였으 며, $\mathrm{FEV} 1 / \mathrm{FVC}<70 \%$ 인 경우를 COPD group(n=30), FEV1/ $\mathrm{FVC} \geq 70 \%$ 인 경우를 non-COPD group(n=144)으로 분류하 였다(Fig. 1). 모든 폐 기능 검사는 Spriometer2130(SENSOR- 
Negative Association between COPD and Nasal Polyp I Lee MG, et al.

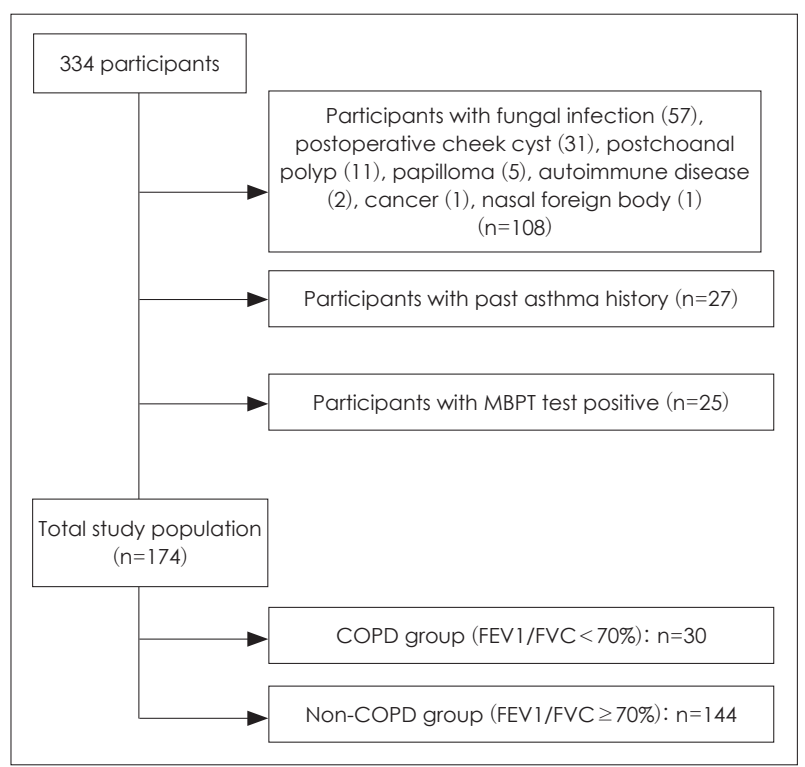

Fig. 1. Flowchart diagram of patient group selection. MBPT: methacholine bronchial provocation test, COPD: chronic obstructive pulmonary disease, FEV: forced expiratory volume, FVC: forced vital capacity.

MEDICS, Inc., Yorba Linda, CA, USA) 기계를 사용하여 시 행하였다. 환자의 비만도는 World Health Organization의 Body Mass Index classification을 기준으로, ${ }^{13)}$ 체중 $(\mathrm{kg}) /\left(ㅋ \mid(\mathrm{m})^{2}\right.$ 로 계산하였으며, 18.5 미만을 저체중(underweight), 18.5 이상-25 미만을 정상(healthy), 25 이상 30 미만을 과체중(overweight), 30 이상을 비만(obese)으로 분류하였으며, 흡연력 비교를 위 해 한 번이라도 담배를 핀 적이 있는 환자를 흡연군(smoker group), 담배를 핀 적이 없는 환자를 비흡연군(non-smoker group)으로 분류하였다.

통계학적 분석을 위해 SPSS 20(SPSS Inc., Chicago, IL, USA) 프로그램을 사용하였고, COPD group과 non-COPD group의 교란변수 항목인 연령, 성별, 비만도, 흡연력 비교를 위하여 Student t-test 및 chi-square test를, 다양한 예후인자 가 비용종 발생에 미치는 영향을 알아보기 위하여 이분형 로 지스틱 회귀 검정방법을 사용하였으며, $p$-value가 0.05 미만 에서 통계학적으로 유의하다고 정의하였다.

\section{결 과}

전체 환자군의 일반적인 특징을 나이, 성별, 비만도, 흡연 력, 비용 동반 여부에 따라 정리하였다(Table 1). 전체 환자 중 COPD group은 30명(17.2\%), non-COPD group은 144명 (82.8\%)이었다. 평균 나이는 COPD group에서 더 많았으며, 이는 통계학적으로 유의하였다 $(p=0.004)$. 성별을 비교해 보 았을 때 COPD group에서 남자의 비율이 더 높았으며, 이는 통
Table 1. General characteristic of total patients

\begin{tabular}{lcccc}
\hline & Total & COPD & Non-COPD & p-value \\
\hline Total number (n) & 174 & 30 & 144 & \\
Age (y) & 59.9 & 63.6 & 59.2 & $0.004^{*}$ \\
Sex (\%) & & & & $0.002^{\dagger}$ \\
$\quad$ Male & $114(65.5)$ & $27(90)$ & $87(60.4)$ & \\
$\quad$ Female & $60(34.5)$ & $3(10)$ & $57(39.6)$ & \\
Obesity (\%) & & & & 0.353 \\
$\quad$ Underweight & $8(4.6)$ & $0(0)$ & $8(5.6)$ & \\
Healthy & $89(51.1)$ & $19(63.3)$ & $70(48.6)$ & \\
$\quad$ Overweight & $68(39.1)$ & $10(33.3)$ & $58(40.3)$ & \\
$\quad$ Obese & $9(5.2)$ & $1(3.3)$ & $8(5.6)$ & \\
Smoking (\%) & & & & 0.228 \\
$\quad$ Non-smoker & $151(86.8)$ & $24(80)$ & $127(88.2)$ & \\
$\quad$ Smoker & $23(13.2)$ & $6(20)$ & $17(11.8)$ & \\
Nasal polyp (\%) & & & & $0.036^{\dagger}$ \\
$\quad$ Negative & $34(19.5)$ & $10(33.3)$ & $24(16.7)$ & \\
Positive & $140(80.5)$ & $20(66.7)$ & $120(83.3)$ & \\
\hline
\end{tabular}

*Student t-test, significance at $p<0.05$, tchi-square test, significance at $p<0.05$. COPD: chronic obstructive pulmonary disease

Table 2. AOR of possible risk factors for nasal polyp in elderly chronic rhinosinusitis patients

\begin{tabular}{lll}
\hline Patients characteristics & \multicolumn{1}{c}{ AOR $(95 \% \mathrm{Cl})$} & p-value \\
\hline Age & $1.058(0.995-1.126)$ & 0.073 \\
Sex & & \\
$\quad$ Male & 1 & 1 \\
$\quad$ Female & $0.897(0.366-2.415)$ & 0.897 \\
Smoking & & \\
$\quad$ Non-smoker & 1 & 1 \\
$\quad$ Smoker & $0.434(0.154-1.219)$ & 0.113 \\
Obesity & & 0.271 \\
$\quad$ Healthy & 1 & 1 \\
$\quad$ Underweight & $3.833(0.781-18.808)$ & 0.098 \\
Overweight & $5.169(0.996-26.814)$ & 0.051 \\
Obese & $2.911(0.335-25.329)$ & 0.333 \\
FEV 1 FVC & & \\
$\quad$ 70\% (Non-COPD) & 1 & 1 \\
$<70 \%$ (COPD) & $0.288(0.102-0.809)$ & $0.018^{*}$ \\
\hline
\end{tabular}

*significance at $p<0.05$. Cl: confidence interval for the difference, AOR: adjusted odds ratio, FEV 1: forced expiratory volume, FVC: forced vital capacity

계학적으로 유의하였다 $(p=0.002)$. 두 군에서 비만도 $(p=0.353)$, 흡연 유무 $(p=0.228)$ 에 따른 통계학적으로 유의한 차이는 없 었다. 전체 환자 중 비용종이 있는 환자는 140명(80.5\%)이었 으며, COPD group에서 20명(66.7\%), non-COPD group에서 120명(83.3\%)으로 non-COPD group에서 COPD group보다 비용종이 있는 환자의 비율이 더 높았으며, 이는 통계학적으 로 유의하였다 $(p=0.036)$.

비용종의 발생에 $\mathrm{FEV} 1 / \mathrm{FVC}$ 가 유의한 위험인자임을 확인 
하기 위하여 로지스틱 중회귀 분석을 시행하였다(Table 2). 나 이, 성별, 흡연력, 비만도, FEV1/FVC의 5가지 변수에 대해 회 귀분석을 시행하였다. 나이가 많을수록 비용을 더 가지고 있 을 기여도가 1.058[95\% confidence interval for the difference $(\mathrm{CI})=0.995-1.126]$ 이었으며, 이는 통계학적으로 유의하지 않 았다 $(p=0.073)$. 여자는 남자에 비해 비용을 가지고 있을 기여 도(adjusted odds ratio, $\mathrm{AOR}$ )가 0.897(95\%, CI $=0.366-2.415)$ 이었으며, 이는 통계학적으로 유의하지 않았다 $(p=0.897)$. 흡 연자는 비흡연자에 비해 비용을 가지고 있을 기여도가 0.434 (95\% CI=0.154-1.219)이었으며, 이는 통계학적으로 유의하지 않았다 $(p=0.113)$. 비만도에 따라 기여도를 확인한 결과 정상 체중군에 비해 비용을 가지고 있을 기여도가 저체중 환자군 은 3.833(95\% CI=0.781-18.808), 과체중 환자군은 5.169(95\% $\mathrm{CI}=0.996-26.814)$, 비만 환자군은 $2.911(95 \% \mathrm{CI}=0.335-$ 25.329)이었으며, 각 군에서 이는 모두 통계학적으로 유의하 지 않았다(저체중 환자군 $p=0.098$, 과체중 환자군 $p=0.051$. 비만 환자군 $p=0.333) . \mathrm{FEV} 1 / \mathrm{FVC}$ 결과에 따라 기여도를 확 인한 결과 COPD group의 경우, non-COPD group에 비해 비 용을 가지고 있을 기여도가 0.288(95\% CI=0.102-0.809)로, 오히려 비용을 가지고 있지 않을 확률이 낮은 것으로 확인되 었으며, 이는 통계학적으로 유의하였다 $(p=0.018)$.

\section{고 찰}

본 연구에서는, 비용종의 발생에 만성 폐쇄성 폐질환이 연 관이 있는지 조사하였다. 모든 환자에게서 메타콜린 기관지 유발검사를 시행하여 천식 환자 및 $\mathrm{ACOS}$ 환자를 모두 제외 한, 만성 폐쇄성 폐질환 환자만을 대상으로 하였다. 연구 결과, COPD group은 non-COPD group보다 연령이 더 많았으며 ( $p=0.004)$, 남성의 비율이 더 높았다 $(p=0.002)$. 반면, $\mathrm{COPD}$ group의 경우 non-COPD group보다 비용종이 동반되지 않 을 확률이 더 높았고 $(p=0.036)$, 비용종의 발생에 영향을 미 치는 위험인자를 분석한 결과, 만성 폐쇄성 폐질환이 있는 경우 만성 폐질환이 없는 경우보다 기여도가 $0.288(95 \% \mathrm{CI}=$ 0.102-0.809)로 더 낮았으며, 이는 통계학적으로 유의하였다 ( $p=0.018)$.

만성 폐쇄성 폐질환과 상기도 질환의 연관성은 이미 잘 알려 져 있다. 만성 폐쇄성 폐질환 환자에서 비증상이 나타나는 빈 도는 75 88\%로 높게 나타나고 있으며, ${ }^{14)} 8469$ 명의 남부 스웨 덴 성인을 대상으로 한 설문조사 결과 만성 폐쇄성 폐질환을 가진 환자의 $40 \%$ 가 비증상을 가지는 것으로 나타나, 전체 인 구의 $33 \%$ 가 비증상을 가지는 것에 비해 유의하게 많다고 보 고하였다. ${ }^{15)}$ 또한 폐기능 검사로 진단된 만성 폐쇄성 폐질환
환자에게서 만성 비증상의 빈도를 조사한 연구 결과, 61 명의 환자군 중 $75 \%$ 가 정기적으로 비증상을 호소한다고 보고하 였다. ${ }^{16)}$

또한, 최근 여러 연구에서 만성 폐쇄성 폐질환 환자에서 비 부비강 염증이 잘 동반되는 것을 보고하였다. Hurst 등기 이 14 명의 만성 폐쇄성 폐질환 환자와 14 명의 대조군을 비교한 연구에 의하면, 만성 폐쇄성 폐질환 환자의 비강 세척액에서 염증반응에 관련되어 있는 것으로 알려져 있는 interleukin 8 이 대조군보다 유의하게 더 검출되었으며, Thomson 등이 이 31 명의 만성 폐쇄성 폐질환 환자와 23명의 대조군을 비교한 연구에 의하면, 만성 폐쇄성 폐질환 환자의 비액에서 eotaxin, G-CSF 등의 염증 매개 인자가 대조군보다 유의하게 많은 양 이 검출되었다고 보고하였다.

여러 연구에서 만성 폐쇄성 폐질환과 만성 비부비동염이 유의한 연관이 있다는 것이 보고되었으나, 만성 폐쇄성 폐질 환이 비용종에 미치는 영향에 대하여는 시행된 연구가 거의 없 는 상황이다.

본 연구에서는, 만성 폐쇄성 폐 질환에서 국소(기도 및 혈관) 및 전신적 염증과 저산소증은 매우 빈번하게 발생하는 것으 로 알려져 있고, ${ }^{9)}$ 저산소증은 renin-angiotensin 작용을 활 성화시켜, 국소 혈관수축을 유발, 신장 혈류량을 증가시키 며, ${ }^{18)}$ 국소 혈관수축은 비강 및 기도에도 발생, 해당 부위의 관류량을 감소시켜 국소 저산소증을 유발하므로, 이는 비강 의 $\mathrm{HIF}-1 \alpha$ 의 발현을 촉진시켜 비용종의 발생이 증가될 것이 라고 생각하고 연구를 진행하였다.

그러나 자료 분석 결과, 오히려 만성 폐쇄성 폐질환 군에서 비용종의 발생이 감소하는 것을 확인하였다. 이에 대하여 관 련된 다른 연구를 확인한 결과, Keller 등 ${ }^{19}$ 은 비용이 동반되 지 않은 만성 비부비동염은 비용이 동반된 만성 비부비동염 과 매우 다른 병리생리학적 특징을 가지고 있다고 하였고, Chandra 등 ${ }^{20)}$ 은 호산구성 비용이 동반된 만성 비부비동염 이 T-helper 2 반응과 조직내 호산구증을 주로 보이는 반면, 비용이 동반되지 않은 비부비동염은 T-helper 1(Th1) 반응과 주로 호중구에 의해 발생하는 염증 반응을 보인다고 하였다. 만성 폐쇄성 폐질환도 이와 유사하게 Th1 반응이 주로 관찰 되며, ${ }^{19)}$ 호중구에 의한 염증 반응이 증가하는 것이 관찰된 다. ${ }^{21)}$ 최근 연구에서 만성 폐쇄성 폐질환이 동반된 환자에게 서 과립구 집락 자극인자(granulocyte colony-stimulating factor)가 증가하는 것을 보고하였는데,') 과립구 집락 자극인 자는 과립구 발생 및 발현을 자극하는 성장인자로 알려져 있 으며, 이는 기도 표피 세포에 의해 만들어질 수 있으며, 이는 호중구성 기도 염증을 유발한다. 이러한 호중구성 기도 염증 은 상기도에도 영향을 미치게 되어, 만성 폐쇄성 폐질환 환자 
에게서 상기도 염증 반응이 있는 경우 호중구 침윤이 주로 관 찰되게 된다. ${ }^{22,23)}$ 최근 대만에서 시행된 연구에 의하면, 만성 폐쇄성 폐질환 환자에게서 비용이 동반되지 않은 만성 비부 비동염의 발생이 유의하게 증가하였으며, 이는 만성 폐쇄성 폐질환에서 주로 발생하는 Th1 response에 영향을 받은 비 강에서 Th1 반응이 주로 일어나는 비용이 동반되지 않은 비 부비동염의 발생에 영향을 미치기 때문이라고 하였다. ${ }^{24)}$

상기 연구 결과로 미루어 보았을 때, 본 연구에서 만성 폐쇄 성 폐질환이 있는 경우 비용종의 발생이 오히려 저해된 이유는, 만성 폐쇄성 폐질환 환자에서 발생할 수 있는 비강의 저산소 상태가 예상보다 심하지 않고, 그에 비하여 만성 폐쇄성 폐 질환에서 동반되는 호중구성 염증 반응 및 Th1 면역 반응 편위가 더 큰 영향을 미쳤기 때문이라고 생각할 수 있다. 특 히, 고령 환자의 경우, 만성 폐쇄성 폐질환의 정도가 심한 경 우가 많으며, 이는 더 심한 호중구성 염증 상태를 유발시키 므로 다른 연령군보다 비용이 동반되지 않은 만성 비부비동 염의 발생이 더 심해질 것이라고 생각된다.

본 연구는 몇 가지 한계를 가지고 있다. 첫째로, 본 연구는 후향적 연구로 진행되었으므로, 만성 폐쇄성 폐질환과 비용 이 동반되지 않은 만성 비부비동염이 연관이 있는 것은 알 수 있으나 만성 폐쇄성 폐질환이 비용종의 발생 저하에 미치 는 영향에 있어 인과성이 있는지 추적 관찰할 수는 없다. 둘 째로, 본 연구는 상기도 질환과 하기도 질환이 별개의 질환 이 아닌 하나로 연관되어 있다는 전제로 진행하였으나, 선행 된 타 연구들이 모두 서양 환자를 대상으로 했기 때문에 동 양인에게서 시행한 본 연구의 경우에는 이와는 다른 영향을 미칠 가능성을 배제할 수 없다. 셋째로, 본 연구에서는 흡연 여부에 대한 조사 외 흡연기간, 흡연량, 최근 흡연량에 대한 조사가 이루어지지 않아 흡연력에 대한 정량화가 이루어지지 않았으며, 이로 인해 비용종 발생 및 악화에 유의한 영향을 미치는 것으로 알려져 있는 흡연력이 ${ }^{25)}$ 본 연구에서는 유의 한 영향이 없는 것으로 분석된 것으로 보인다. 넷째로, 본 연 구에서는 만성 폐쇄성 폐질환의 호중구 침윤 및 Th1 면역 반 응 편위 상태를 각 환자에서 조사하지 않아 만성 폐쇄성 폐 질환이 만성 비부비동염에서 비용의 발생 저하를 유발하는 분 자생리학적 기전을 실험적으로 입증할 수가 없다.

여러 한계점에도 불구하고, 이 연구는 만성 폐쇄성 폐질환 과 비용의 발생 감소 빈도가 상관성이 있다는 것을 확인한 논문으로 의의가 있으며, 향후 이에 대한 실험적 연구가 뒷받 침되어야 할 것으로 생각된다.

\section{REFERENCES}

1) de Benedictis FM, del Giudice MM, Severini S, Bonifazi F. Rhinitis, sinusitis and asthma: one linked airway disease. Paediatr Respir Rev 2001;2(4):358-64.

2) Passalacqua G, Ciprandi G, Canonica GW. The nose-lung interaction in allergic rhinitis and asthma: united airways disease. Curr Opin Allergy Clin Immunol 2001;1(1):7-13.

3) Leynaert B, Neukirch F, Demoly P, Bousquet J. Epidemiologic evidence for asthma and rhinitis comorbidity. J Allergy Clin Immunol 2000;106(5 Suppl):S201-5.

4) Pfister R, Lütolf M, Schapowal A, Glatte B, Schmitz M, Menz G. Screening for sinus disease in patients with asthma: a computed tomography-controlled comparison of A-mode ultrasonography and standard radiography. J Allergy Clin Immunol 1994;94(5):804-9.

5) Kim JS, Rubin BK. Nasal and sinus involvement in chronic obstructive pulmonary disease. Curr Opin Pulm Med 2008;14(2): 101-4.

6) Hens G, Vanaudenaerde BM, Bullens DM, Piessens M, Decramer M, Dupont LJ, et al. Sinonasal pathology in nonallergic asthma and COPD: 'united airway disease' beyond the scope of allergy. Allergy 2008;63(3):261-7.

7) Fokkens WJ, Lund VJ, Mullol J, Bachert C, Alobid I, Baroody F, et al. EPOS 2012: European position paper on rhinosinusitis and nasal polyps 2012. A summary for otorhinolaryngologists. Rhinology 2012;50(1):1-12.

8) Pauwels RA, Buist AS, Calverley PM, Jenkins CR, Hurd SS; GOLD Scientific Committee. Global strategy for the diagnosis, management, and prevention of chronic obstructive pulmonary disease. NHLBI/ WHO Global Initiative for Chronic Obstructive Lung Disease (GOLD) Workshop summary. Am J Respir Crit Care Med 2001;163 (5):1256-76

9) Asia Pacific COPD Roundtable Group. Global Initiative for Chronic Obstructive Lung Disease strategy for the diagnosis, management and prevention of chronic obstructive pulmonary disease: an AsiaPacific perspective. Respirology 2005;10(1):9-17.

10) Lee SH, Lee SH, Kim CH, Yang KS, Lee EJ, Min KH, et al. Increased expression of vascular endothelial growth factor and hypoxia inducible factor- $1 \alpha$ in lung tissue of patients with chronic bronchitis. Clin Biochem 2014;47(7-8):552-9.

11) Shin HW, Cho K, Kim DW, Han DH, Khalmuratova R, Kim SW, et al. Hypoxia-inducible factor 1 mediates nasal polypogenesis by inducing epithelial-to-mesenchymal transition. Am J Respir Crit Care Med 2012;185(9):944-54.

12) Papaiwannou A, Zarogoulidis P, Porpodis K, Spyratos D, Kioumis I, Pitsiou G, et al. Asthma-chronic obstructive pulmonary disease overlap syndrome (ACOS): current literature review. J Thorac Dis 2014;6 Suppl 1:S146-51.

13) Physical status: the use and interpretation of anthropometry. Report of a WHO Expert Committee. World Health Organ Tech Rep Ser 1995;854:1-452.

14) Hurst JR. Upper airway. 3: Sinonasal involvement in chronic obstructive pulmonary disease. Thorax 2010;65(1):85-90.

15) Montnémery P, Svensson C, Adelroth E, Löfdahl CG, Andersson $\mathrm{M}$, Greiff L, et al. Prevalence of nasal symptoms and their relation to self-reported asthma and chronic bronchitis/emphysema. Eur Respir J 2001;17(4):596-603.

16) Roberts NJ, Lloyd-Owen SJ, Rapado F, Patel IS, Wilkinson TM, Donaldson GC, et al. Relationship between chronic nasal and respiratory symptoms in patients with COPD. Respir Med 2003;97(8):909-14.

17) Hurst JR, Wilkinson TM, Perera WR, Donaldson GC, Wedzicha JA. Relationships among bacteria, upper airway, lower airway, and systemic inflammation in COPD. Chest 2005;127(4):1219-26.

18) Thomson AJ, Drummond GB, Waring WS, Webb DJ, Maxwell SR. Effects of short-term isocapnic hyperoxia and hypoxia on cardiovascular function. J Appl Physiol (1985) 2006;101(3):809-16.

19) Keller JJ, Wu CS, Lin HC. Increased risk of psoriasis following chronic 
rhinosinusitis without nasal polyps: a population-based matchedcohort study. Br J Dermatol 2013;168(2):289-94.

20) Chandra RK, Lin D, Tan B, Tudor RS, Conley DB, Peters AT, et al. Chronic rhinosinusitis in the setting of other chronic inflammatory diseases. Am J Otolaryngol 2011;32(5):388-91.

21) Kim JS, Rubin BK. Nasal and sinus inflammation in chronic obstructive pulmonary disease. COPD 2007;4(2):163-6.

22) Nihlén U, Andersson M, Löfdahl CG, Persson CG, Montnémery P, Greiff L. Nasal neutrophil activity and mucinous secretory responsiveness in COPD. Clin Physiol Funct Imaging 2003;23(3): $138-42$.
23) Vachier I, Vignola AM, Chiappara G, Bruno A, Meziane H, Godard $\mathrm{P}$, et al. Inflammatory features of nasal mucosa in smokers with and without COPD. Thorax 2004;59(4):303-7.

24) Chien CY, Tai SY, Wang LF, Lee CT. Chronic obstructive pulmonary disease predicts chronic rhinosinusitis without nasal polyps: a population-based study. Am J Rhinol Allergy 2015;29(3):e75-80.

25) Lee KI, Kim DW, Kim EH, Kim JH, Samivel R, Kwon JE, et al. Cigarette smoke promotes eosinophilic inflammation, airway remodeling, and nasal polyps in a murine polyp model. Am J Rhinol Allergy 2014;28(3):208-14. 